\title{
FEEDING PREFERENCES OF APHIDOPHAGOUS COCCINELLIDS (COLEOPTERA: COCCINELLIDAE) BY ALFALFA APHIDS (HEMIPTERA: APHIDIDAE) IN \\ LABORATORY
}

\author{
Suzan Beatriz Zambon da Cunha ${ }^{1}$, Carlos Roberto Sousa e Silva ${ }^{1}$ \\ ${ }^{1}$ Universidade Federal de São Carlos, São Carlos, SP, Brasil. E-mail: suzanbio@yahoo.com.br, dcrs@ufscar.br
}

\begin{abstract}
This paper deals with the feeding preferences of Cycloneda sanguinea, Harmonia axyrids and Hippodamia convergens (Coleoptera: Coccinellidae) by the alfalfa aphids Acyrthosiphon pisum, Aphis craccivora and Therioaphis maculata, in laboratory. One observed that the predators selected the prey for they did not consume the first aphid species found. The results of the Ivlev Electivity Index indicated that most of the coccinellids showed a preference for Aphis craccivora.
\end{abstract}

Keywords: Medicago sativa, ladybugs, predators

\section{SELETIVIDADE ALIMENTAR DE COCCINELÍDEOS (COLEOPTERA: COCCINELLIDAE) POR AFÍDEOS (HEMIPTERA: APHIDOIDEA) PRAGAS DA ALFAFA}

\section{RESUMO}

Verificou-se em laboratório se há seletividade alimentar das espécies Cycloneda sanguinea, Harmonia axyridis e Hippodamia convergens pelos afídeos Acyrthosiphum. pisum, Aphis craccivora e Therioaphis maculata, pragas da cultura de alfafa. Observou-se que os predadores selecionaram a presa, não consumindo a primeira espécie de afídeo encontrada. Os resultados dos cálculos do Ìndice de Eletividade de Ivlev, revelaram que a maioria dos coccinelídeos testados demonstrou preferência por Aphis craccivora.

Palavras-chave: Medicago sativa, joaninhas, predadores 


\section{INTRODUCTION}

The aphids (Hemiptera: Aphidoidea) are considered the most important economic pests of alfalfa (Medicago sativa L.) crops, for they generally occur in high population levels. They have direct action, by sucking the plant sap, and indirect action by inoculating virus into de alfalfa plants. Associated to the aphid colonies one finds many predator species namely the coccinellids. Although there is no exclusively aphidophagous species among the Coccinellidae (SARAN et al 2007), some species present a high preference for aphids, such as Cycloneda, Harmonia and Hippodamia (GIORGI et al., 2009). Because Hippodamia convergens maintains the aphid population under control in California, this motivates its introduction in many countries, including Brazil, to be used in programs of biological control (KATO et al., 1999). This species is also referred in Argentina as an efficient agent of aphid control in alfalfa crops (ARAGON, 1990 according to SOUSA-SILVA et al., 1998). Harmonia. axyridis is an Asian species, introduced in Brazil in 2002, in the state of Paraná, where it was observed feeding on aphid pests of Pinus. This species is considered a predator of aphids, psyllids and coccids and worldly used in biological control programs (ALMEIDA \& SILVA, 2002). In Japan, the species is one of the main aphid predators in alfalfa crops (RAKHSHANI et al., 2009). Although the introduction of H. axyridis is registered for more than 10 years ago, there are few information about its biology and feeding preference (SANTOS et al., 2009). Cycloneda sanguinea, Harmonia axyridis and Hippodamia convergens are species commonly found in high numbers in alfalfa crops. In São Carlos, State of São Paulo, they are easily collected in alfalfa fields, preying the aphids Acyrthosiphon pisum, Aphis craccivora and Therioaphis maculata (SOUSA- SILVA et al., 1998). Therefore, the objective of this research was to verify, in laboratory, if there is any feeding selectivity of the species Cycloneda. sanguinea, Harmonia axyridis and Hippodamia. convergens concerning the aphids Acyrthosiphum pisum, Aphis. craccivora and Therioaphis maculata.

\section{MATERIAL AND METHODS}

Coccinellids and aphids used in the feeding selectivity tests were collected in alfalfa fields, cultivar Crioula, in the "Unidade da Embrapa Pecuária Sudeste - CPPSE", in the region of São Carlos, State of São Paulo, Brazil. 
The experiment was carried out at the Laboratory of Applied Entomology, Department of Ecology and Evolutive Biology, University of São Carlos, in São Carlos, State of São Paulo, Brazil, at room temperature $\left(27^{\circ} \mathrm{C}\right), 65 \%$ of relative humidity and 12-hours photophase.

The tests were done with chance of choice in a completely randomized experimental design with three treatments and 50 replications per treatment. In each treatment, one species of coccinellid and four adults of each aphid species, totalizing 12 aphids, were used. The coccinellids were kept in fasting for 48 hours before beginning the tests and the parameters used for observation, analysis and interpretation of the obtained data were: searching for the prey, species initially consumed and total number of specimens of each prey species consumed. In petri dish containing only one coccinellid one added 12 adult aphids, being four of each aphid species. Two hours after the beginning of the tests the remaining food material was registered and afterwards one calculated the Ivlev Electivity Index (KREBS, 1989) to see if there was or there was not preference for the offered material.

The index was calculated according to the model:

$$
\begin{aligned}
& \mathrm{IEI}=(r i-n i) /(r i+n i) \text { where: } \\
& \mathrm{EI}=\text { electivity index for the prey I } \\
& r i=\text { relative abundance of each item consumed } \\
& n i=\text { relative abundance of each item in the environment }
\end{aligned}
$$

The values of the index may vary between 0 and +1.0 conditioning prey preference or positive selection, and between -1.0 and 00 conditioning prey rejection or absence of selection. Results of 0 value condition neutrality.

\section{RESULTS AND DISCUSSION}

The evaluations to determine which aphid species was firstly consumed by the predators indicated that most of the three coccinellids species selected A.craccivora

From the tested coccinellids, $56.7 \%$ of C.sanguinea, $61.8 \%$ of Harmonia axyridis, and $50.1 \%$ of Hippodamia convergens firstly comsumed A.craccivora, while A.pisum was firstly consumed by $25 \%$ of C.sanguinea, $16.6 \%$ of H.axyridis, and 33,3\% of H.convergens. On the other hand, T.trifolli was first consummed by only $18.3 \%$ of C.sanguinea, $21.6 \%$ of H.axyridis, and $16.6 \%$ of H.convergens. 
The results of the Ivlev Electivity Index for the 50 specimens of each coccinellid species indicated that: for C.sanguinea seven were neutral, one preferred T.trifolii, and 42 preferred A.craccivora; for H.axyridis, five were neutral, one preferred A.pisum, and 44 preferred A.craccivora; for H.convergens, five were neutral, one preferred preferred, T.trifolii and 44 preferred A.craccivora. One calculated the mean of the Ivlev Electivity Index for the preys A.craccivora, A.pisum and T.trifolii (Table 1).

Table 1. Mean of the Ivlev Electivity Index for the preys A.craccivora, A.pisum and T.trifolii consumed in laboratory by $C$. sanguinea, $H$. axyridis and $H$. convergens. Positive values condition preference or positive selection, while negative values condition rejection or absence of prey selection by the predator

\begin{tabular}{lccc}
\hline Predator & \multicolumn{4}{l}{ Mean of the Ivlev Electivity Index of the preys } \\
\hline & A. craccivora & A. pisum & T. trifolii \\
\hline C. sanguinea & $+0,22$ & $-0,35$ & $-0,17$ \\
H. axyridis & $+0,22$ & $-0,35$ & $-0,25$ \\
H. convergens & $+0,20$ & $-0,33$ & $-0,15$ \\
\hline
\end{tabular}

\section{CONCLUSION}

The coccinellids $C$. sanguinea, $H$. axyridis and $H$. convergens showed preference for $A$. craccivora when one considers the other alfalfa aphids.

\section{ACKNOWLEDGEMENT}

To the "Conselho Nacional de Desenvolvimento Científico e Tecnológico (CNPq)" for the financial support.

\section{REFERENCES}

ALMEIDA, L.M.; SILVA, V.B. 2002. Primeiro registro de Harmonia axyridis (Pallas) (Coleoptera: Coccinellidae): um coccinelídeo originário da região paleártica. Revista Brasileira de Zoologia, Curitiba, v.19, n.3, p. 941-944.

GIORGI, J.A.; VANDENBERG, N.J.; MCHUNG, J.V.; FORRESTER, J.A.; SLIPINSKI, A.; MILLER, K.B.; SHAPIRO, L.R.; WHITING, M.F. 2009. The evolution of food preferences in coccinellidae. Biological Control, Netherlands, v.51, p. 215-231.

KATO, C. M.; BUENO, V. H. P.; MORAIS, J. C.; AUAD, A. M. 1999. Criação de Hippodamia convergens Guérin-meneville (Coleoptera: Coccinellidae) em ovos de Anagasta kuehniella (Zeller) (Lepidoptera: Pyralidae). Anais da Sociedade Entomológica do Brasil, Londrina, v. 28, n. 3, p. 455-459.

KREBS, C. J. 1989. Ecological Methodology. New York, Harper Collins Publishers. 654p. 
RAKHSHANI, H.; EBADI, R.; MAHAMMADI, A. A. 2009. Population dynamics of alfalfa aphids and their natural enemies, Isfahan, Iran. Journal of Agricultural Science and Technology, Tehran v.11, p. 505-520.

SARAN, E.D.; THOMAZONI, D.; SERRA, A.P.; DEGRANDE, P. 2007. Manual dos insetos benéficos do algodoeiro. FMC- Química do Brasil- Campinas, v.1, 227p.

SANTOS, N.R.P; SANTOS-CIVIDANES, T.M.; CIVIDANES F.J.; ANJOS, A.C.R; OLIVEIRA, L.V.L. 2009. Aspectos biológicos de Harmonia axyridis alimentada com duas espécies de presas e predação intraguilda com Eriopis connexa. Pesquisa Agropecuária Brasileira, Brasília, v. 44, n.6, p 554-560.

SOUSA-SILVA, C. R.; PACHECO, J. M.; RASSINI, J. B.; ILHARCO, F. A. 1998. Afídeos da alfafa no Brasil (Homoptera, Aphidoidea). Revista Brasileira de Entomologia, Curitiba, v.41, n.2-4 p. 285-288. 